\title{
Mastering Students' Speaking Skill using Inquiry Online Project-based Strategy
}

\author{
Faizul Muna1, Imam Nur Aziz² \\ 1,2 Department of English Education, Institut Keislaman Abdullah Faqih Gresik, Indonesia \\ E-mail: ${ }^{1}$ faizulmuna59@gmail.com*, ${ }^{2}$ imamnuraziz@gmail.com \\ *Coresponding Author
}

Article History: Received: November, 17 2020; Accepted: March, 20 2021; Published: April, 32021

\begin{abstract}
This study focuses on the use of an online learning research project focused on students' speaking skills. It is an innovative and practical approach that can develop students to solve a problem by thinking critically. This study aimed to determine the effect of using inquiry project-based learning on students' speaking skills. The research was conducted at MTs Mambaus Sholihin Gresik in class VII Q. To determine whether inquiry-project-based online learning is effective or not, researchers used a preexperimental method, where the statistical formula of the t-test calculates information. The research result is that the pre-test's mean was 83.9189 , and the norm of the post-test was 88.5135 . The results showed that inquiry-project-based online learning projects had a positive effect on students' speaking achievement. It means that there is a large effect, with a substantial difference in student scores before and after treatment. Thus it can be concluded that inquiry-project-based online learning is recommended to promote students' speaking skills.
\end{abstract}

Keywords: Online Learning, Speaking Skill, Inquiry Online Project-based Strategy

\section{Copyright $\odot 2021$ The Author(s)}

This is an open-access article under the CC BY-SA license.

\section{INTRODUCTION}

The research stance must be included, whether it corrects, debates, or support the previous research. In order to improve the quality of school education and learning in the future, it is crucial to change the thinking that will be used as the basis for the implementation of learning programs (Silalahi \& Hutauruk, 2020). Mastering communication skills is crucial in studying a foreign language, especially English, as the world's French language. Learning to communicate in English should allow the learner to practice your skills. The tutor must then enable the learners to practice their speaking skills (Aziz \& Dewi, 2020). English is an important phrase used as a medium of communication. It is used as a medium for various purposes, such as education, business, tourism, etc. (Sirisrimangkorn, 2018). English is the required foreign language used by people who speak different primary languages. Speech skills become the main effect of the anxiety of language learners (Sutarsyah, 2017). Speech is a valuable ability since people use it to communicate for many reasons and functions. The vital purpose of learning English is to be able to communicate effectively in English. According to (Bygate, 2012) speaking requires the development of a specific form of communication skills. Speech skills refer to the ability to 
behave in a language typically characterized by speaking a language. It is seen as an important way of learning to articulate meaning and communicate effectively. Various communicative strategies have been used to develop the ability of learners to communicate.

Inquiry-Project-based learning approaches have been promoted as instructional methods for students at all stages. This method helps students to discover or acquire knowledge through similar activities and personal investigations. (Johnson, 2016). (Liu \& Chu, 2010) He believed that the pervasive environment led to improved speech skills and increased motivation among young EFL learners but did not specify which aspects of speech skills had improved.

Online learning and training are becoming increasingly popular globally, reducing the temporal and spatial problems associated with traditional education forms. The key drivers behind online learning are improving access to and quality education and training, reducing costs and improving education's cost-effectiveness (Bates, 1997). Online learning, combined with face-to-face learning, is successfully used in both industry and academia with positive outcomes (Chang, 2016). At the same time, the geographically scattered company team will obtain their skills training via online platforms while at the same time achieving a higher level of competitiveness. Online learning is also useful for students to research at their own pace using online content (Panigrahi et al., 2018).

To pop up the progress and develop student's speaking skills are not accessible. It can be seen more in the first grade of the MTs Mambaus Sholihin Suci Manyar Gresik, although their teachers led them. By observing in class, there are several problems: the lack of vocabulary, which is one obstacle for speaking students. Besides, students lack confidence in the study, and students cannot understand or process what students want to say. Some students are not excited and bored in the learning process because they use teaching techniques that students consider monotonous. These problems must be explained that it becomes a challenge for students to speak and understand the material.

Monotonous teaching will not enhance student learning optimally, as students are not interested, inspired, and do not feel a purpose for learning activities. Researchers also noticed a lack of motivation in this research, as students did not feel the practice's importance or intent. However, since curricular subjects are described as science, participation, literacy, and learning for all students, learning outcomes are clear, and students experience skills and achievement. The induction method promotes student ownership, a sense of control, choice and autonomy, specific learning objectives, teamwork, and personal relevance.

Contribution Inquiry-project-based online learning was selected in teaching speaking to improve the speaking skill of the students. That is a combination of three methods; inquiry learning, project-based learning, and online learning. This method can make students think critically in solving problems and improve student speaking to use the appropriate manner. Inquiry project-based online learning is suitable as a way to overcome this problem.

In light of the clarification, the researcher is inspired to conduct a research entitled "The Effect of Inquiry Project Based Online Learning to Students' Speaking Skill."

\section{Inquiry-based Learning}

The inquiry is an intentional process of diagnosing situations, formulating problems, criticizing tests and distinguishing alternatives, preparing questions, exploring conjectures, investigating data, constructing models, discussing with peers using evidence and representations, and forming coherent arguments (Constantinou et al., 2018). The constructivist view of teaching has theorized, such as John Dewey, Thomas Kuhn, Jean Piaget, and Lev Vygotsky. They believe that knowledge is founded on personal experience and is not gained by providing information (Kim, 2005).

The learner's capacity to make sense of the story influences the internalization of the information and can create new insights and schemes. Constructivist teaching requires research 
instruction since it poses relevant questions for students, constructs through logical comprehension, acknowledges student perspectives, and provides a versatile curriculum that adapts to student deductions. It inspires students to work together, ask questions, discuss new ideas, and take action (Johnson \& Cuevas, 2016). Learning are related to educational approaches, such as constructivist instruction (Kim, 2005), exploratory learning, problem-based learning (Rotgans \& Schmidt, 2011), and project-based learning (Chu et al., 2011), and all of these approaches may fall within a formal open investigative research framework (SpronkenSmith et al., 2012). (Saunders-Stewart et al., 2015) Established a concept of research that is differentiated by the process of activities that improve cognitive skills such as critical thinking, the interaction of content between students and materials contributes to deeper understanding and implementation, the environmental context determines the experience in which research will be performed, and the approach strategy taken by the researcher to carry out the research.

\section{Project-Based Learning}

The project-based program promotes the study of second and foreign languages. (Sirisrimangkorn, 2018). It is used to develop learners in many fields. Project-based learning benefits include creativity, language skills, group work, learning material, self-confidence, autonomy, and decision-making skills. Project-based learning is defined as an instructional model that organizes project-based learning. Students have different roles to play in the project and are expected to complete the finished product. The tasks include design, problem-solving, decision-making, investigation of accidents, and so on. Project-based learning seeks to improve student skills through practical project-based activities. Project-based learning is useful because it solves real-world challenges and helps students to show their skills realistically.

Besides, it engages learners in ongoing investigations and encourages learners to participate in various activities in practical situations. For language teaching, Project-based learning allows teachers to achieve different educational objectives, such as promoting communication, integrating cultural studies into language, connecting language and material, and creating parallels between students' first and second languages. Besides, project-based learning lets students discuss problems, concepts, or subjects without predefined responses (Johnson, 2016).

Fischer \& Krauss (2018) point out that a project may involve small-scale objects, such as experiments, or that it may be expanded to large-scale works, such as exhibitions, murals, or even full-scale plays. Various research is in place to affirm the efficacy of project-based learning to advance student language skills (Rochmahwati, 2015) explored the effects of project-based learning on students' ability to communicate. Research has shown that there are promising effects on the power of students to share. The students have also demonstrated a strong positive attitude towards introducing project-based learning in the speech class. I looked at introducing project-based information and communication technology learning in the English classroom with 25 students from higher education institutions. The results of the study showed that the students were more motivated to use English. They also experimented with more enjoyable and meaningful learning in a project-based English learning class.

\section{Online Learning}

Online learning provides higher education to increase access to and attract students who may not regularly attend campus (Park \& Kim, 2020). According (Nguyen, 2015) Online learning is a form of distance learning or distance learning that has long been part of the American educational system and has become the largest distance learning field in recent years. For this literature review, both hybrid and blended learning and pure online learning are considered to be online learning since much of the literature compares these two formats to conventional face-to-face wisdom. Purely online courses are distributed around the Internet, and blended or 
mixed learning includes traditional face-to-face lectures, learning over the Internet, and learning facilitated by other technologies.

\section{Speaking Skill}

Speaking is characterized as a mechanism for constructing and expressing meaning through verbal and non-verbal symbols in several contexts. It is considered an essential skill in learning and teaching English as a foreign language (EFL) (AL-Garni \& Almuhammadi, 2019). According to (Ul-Haq et al., 2017), speaking is the 'ability to carry out a conversation in the language. Over the years, speaking has been belittled and disowned. Many teachers have taught this through repeated practice and dialogue (Kayi et al., 2012). However, it has recently been realized that teaching speaking skills help develop students' communication skills to express themselves freely and communicate effectively.

\section{METHODS}

In this analysis, the design of the researcher used in this study was pre-experimental with a quantitative approach. The researcher selected a pre-experimental study as one pre-test-posttest party, which means that the research project-based online learning results can be used by students who speak skills. Thirty-seven participants in this study were in Grade VII of the Mambaus Sholihin Junior High School in Gresik. This research design would like to address classroom problems related to teaching language learning. The pre-test was offered to students before treatment. After the procedure, the post-test was provided to students to assess the student's speaking skills. First, to get the results, students do a pre-test on their speaking skills. Furthermore, students study in an "inquiry project-based online learning," then they work to complete the product. These quantitative data have been analyzed and used to explain the findings and their consequences. Then gave them a post-test on their speaking skill after they finished the end product and encouraged commonly utilizing inquiry project-based online learning.

\section{Population and Sampling}

The subject of this research is the first grade of MTs Mambaus Sholihin. The study chooses VII-Q of MTs Mambaus Sholihin consists of 37 students.

\section{The Technique of Data Collection}

The researcher used the speech test to assess and evaluate the student's ability to speak to obtain the analysis results. In this study, the researcher used a pre-test and post-test. The researcher also collects data from the pre-test and post-test ranking. The researcher did a pretest before implementing the study, project-based online learning, and a post-test after completing the learning process. The first is a pre-test to determine students 'speaking ability. Students are asked questions before applying an inquiry-based online learning project. These questions aim to determine students' perceptions of the use of inquiry-based project-based online learning on speaking skills. Students will be evaluated on their speaking in 3 aspects (grammar, vocabulary, and comprehension). The second post-test is given after applying an inquiry-based online learning project that is used in the class. The second post-test will know about the final score and the difference before and after applying the inquiry project-based online learning.

\section{Data Analysis Technique}

After collecting the data from the pre-test and post-test scores, the researcher analyzed the data. The researcher used a methodology of quantitative analysis using a statistical 
approach. This approach is used to know the significant difference in students' speaking skills before and after the study project. The researcher has utilized the application of IBM SPSS Statistics for windows to analyzed data.

In analyzing the data, the researcher tested normality before calculating the t-test to find out test distribution is normal.

\section{RESULTS AND DISCUSSION}

After performing the study, the researcher has two types of data: pre-test and post-test. Pre-test offered to students before applying for inquiry-project-based online learning. Students have tested their speech abilities in three fields (grammar, vocabulary, and comprehension). The consequence of the student score in the pre-test can be seen as follows:

\section{Paired Samples Statistics}

On table 1 , the pre-test score and the post-test showed that the pre-test average was 83.9189, and the post-test norm was 88.5135. It indicates that the post-test score was better than the pre-test score. The findings of the paired sample statistics show that there are substantial variations between the pre-and post-test scores. The findings support the statement that "the effects of inquiry project-based online learning on student speaking skills."

Table 1. Pre and post-test average

\begin{tabular}{|c|c|c|c|c|c|}
\hline & A. & Mean & $\mathbf{N}$ & Std. Deviation & Std. Error Mean \\
\hline \multirow{2}{*}{ Pair 1} & pre-test & 83.9189 & 37 & 3.93262 & .64652 \\
\hline & post-test & 88.5135 & 37 & 4.54375 & .74699 \\
\hline
\end{tabular}

Post-test that given to the students after applying inquiry-project-based online learning. The post-test is done to know about the final score and the differences before and after applying inquiry-project-based online learning.

\section{Paired Samples Correlations}

Table 2 shows that the pre-test and post-test correlations are $r=0.957$ with the likelihood $(\mathrm{sig})=0.000$. This indicates that the pre-test and post-test had a good correlation because the $r$ value was close to 1 .(Field, 2013), $r=0.10$ was a small effect; $r=0.3$ was a medium $r=0.5$ was a big effect.

Table 2. Pre and post-test

\begin{tabular}{lllll}
\hline & & N & Correlation & Sig. \\
\hline Pair 1 & pre-test \& post-test & 37 & .957 & .000 \\
\hline
\end{tabular}

\section{Paired Samples Test}

From the table 3, the significant value (sig. 2 tailed) was 0.000 , the value $<0.05$ was therefore significant, and the tobtained was 20.199 at a significant level of 0.05 and the degree of freedom 36 . This means that inquiry project-based online learning has been important (Field, 2005) has stated, "If the value is less than 0.05 , then the means of the two conditions are significantly different". 
Table 3. Significant value

\begin{tabular}{|c|c|c|c|c|c|c|c|c|c|}
\hline & & \multicolumn{5}{|c|}{ Paired Differences } & \multirow[t]{3}{*}{$\mathbf{t}$} & \multirow[t]{3}{*}{ df } & \multirow[t]{3}{*}{ Sig. (2-tailed) } \\
\hline & & \multirow[t]{2}{*}{ Mean } & \multirow[t]{2}{*}{$\begin{array}{l}\text { Std. } \\
\text { Deviation }\end{array}$} & \multirow[t]{2}{*}{$\begin{array}{l}\text { Std. Error } \\
\text { Mean }\end{array}$} & \multicolumn{2}{|c|}{$\begin{array}{l}95 \% \text { Confidence Interval } \\
\text { of the Difference }\end{array}$} & & & \\
\hline & & & & & Lower & Upper & & & \\
\hline Pair 1 & $\begin{array}{l}\text { pre-test } \\
\text { post-test }\end{array}$ & -4.59459 & 1.38362 & .22747 & -5.05592 & -4.13327 & -20.199 & 36 & .000 \\
\hline
\end{tabular}

\section{Discussions}

Regarding the research was done in VII Q MTs. Mambaus Sholihin Gresik considered a significant difference between students' speaking skills taught using inquiry project-based online learning and those taught not using inquiry project-based online learning. Based on the posttest result computation, the mean score for the post-test on their Speech was 88.5135 , while the average score for the pre-test was 83.9189 . It can be interpreted that the mean post-test score was higher than the pre-test score.

The researcher also found an essential contribution to speaking skills after being taught online learning based on the study project. It can be seen from the test of the hypothesis that there was a Sig. ( 2 tailed) 0.000 lower than the 0.05 degree of importance. It was meant that $\mathrm{Ha}$ was approved while he was rejected.

The data took that influences inquiry project-based online learning in the teaching and learning process, especially in speaking skills.

\section{CONCLUSION}

Based on the study's findings and discussion, it can be inferred that there are gaps in student-speaking abilities that have been substantially gained from the online learning research project. The researcher also discovered essential speaking skills after being taught online learning based on the study project. The meaningful value (Sig. 2 tailed) was 0.000 , the value < 0.05 was also significant.

Inquiry project-based online learning is beneficial in students thinking critically, speaking skills. The effect of inquiry project-based online learning could improve students' thinking patterns critically by speaking. Using WhatsApp media, students are asked to send voice notes and make videos in their respective opinions after the researcher gives an assignment. Their videos are uploaded to their individual WhatsApp stories, so students will speak as best as possible and as well as possible. Inquiry project-based online learning can motivate them to communicate and increase speaking confidence.

Furthermore, an inquiry-based online learning project was helped the students in a mindset to solve a problem by expressing their ideas, thoughts, and other opinions by speaking up.

This study's finding, the result of the research analysis, proves that students' speaking skills are better than before taught by inquiry project-based online learning.

\section{CONFLICT OF INTEREST}

The authors declare that there is no conflict of interest regarding the publication of this article. Authors confirmed that the paper was free of plagiarism.

\section{ACKNOWLEDGEMENTS (OPTIONAL)}

Alhamdulillahirobbil'alamin, all praise be to Allah SWT, the Almighty, the Merciful, and the Owner of the universe who has blessed me with beautiful things in my life. I would like to express the greatest gratitude to my supervisor, Mr. Imam Nur Aziz, M.Pd, who has been willing to spare her valuable time not only for reading, correcting, and improving my thesis but also for 
encouraging me to finish this thesis. I appreciate $\mathrm{H}$. Moh. Ainun Na'im, the principal of MTs. Mambaus Sholihin Gresik has permitted me to undertake the research. I also thank students of Class VII-Q of MTs. Mambaus Sholihin Gresik for their willingness to participate in this research.

\section{REFERENCES}

AL-Garni, S. A., \& Almuhammadi, A. H. (2019). The Effect of Using Communicative Language Teaching Activities on EFL Students' Speaking Skills at the University of Jeddah. English Language Teaching, 12(6), 72. https://doi.org/10.5539/elt.v12n6p72

Aziz, I. N., \& Dewi, Y. A. S. (2020). The use of PowerPoint as media of language teaching on students' speaking skills. Humanities and Social Sciences Reviews. https://doi.org/10.18510/hssr.2020.8145

Bates, T. (1997). Restructuring the university for technological change. Murdoch University.

Bygate, M. (2012). Speaking. The Oxford Handbook of Applied Linguistics, (2 Ed.), July 2018, 1-14. https://doi.org/10.1093/oxfordhb/9780195384253.013.0004

Chang, V. (2016). Review and discussion: E-learning for academia and industry. International Journal of Information Management, 36(3), 476-485.

Chu, S. K. W., Tse, S. K., \& Chow, K. (2011). Using collaborative teaching and inquiry project-based learning to help primary school students develop information literacy and information skills. Library and Information Science Research. https://doi.org/10.1016/j.lisr.2010.07.017

Constantinou, C. P., Tsivitanidou, O. E., \& Rybska, E. (2018). What Is Inquiry-Based Science Teaching and Learning? (O. E. Tsivitanidou, E. Rybska, C. P. Constantinou, P. Gray, \& L. Louca (eds.); 5th ed.). Springer US. https://doi.org/10.1007/978-3-319-91406-0_1

Field, A. (2005). Discovering statistics using SPSS (2nd ed.). In Discovering statistics using SPSS (2nd ed.).

Field, A. (2013). Discovering statistics using IBM SPSS statistics. In Statistics.

Fischer, T., \& Krauss, C. (2018). Deep learning with long short-term memory networks for financial market predictions. European Journal of Operational Research. https://doi.org/10.1016/j.ejor.2017.11.054

Johnson, S. A. (2016). The Effects of Inquiry Project-Based Learning on Student Reading Motivation and Student Perceptions of Inquiry Learning Processes The Effects of Inquiry Project-Based Learning on Student Reading. 13(1). https://doi.org/10.20429/ger.2016.130102

Johnson, S. A., \& Cuevas, J. (2016). The Effects of Inquiry Project-Based Learning on Student Reading Motivation and Student Perceptions of Inquiry Learning Processes. Georgia Educational Researcher, 13(1). https://doi.org/10.20429/ger.2016.130102

Kayi, H., Bersuker, I. B., \& Boggs, J. E. (2012). Pseudo Jahn-Teller origin of bending instability of triatomic molecules. Journal of Molecular Structure. https://doi.org/10.1016/j.molstruc.2012.03.072

Kim, J. S. (2005). The effects of a constructivist teaching approach on student academic achievement, selfconcept, and learning strategies. Asia Pacific Education Review. https://doi.org/10.1007/BF03024963

Liu, T. Y., \& Chu, Y. L. (2010). Using ubiquitous games in an English listening and speaking course: Impact on learning outcomes and motivation. Computers and Education. https://doi.org/10.1016/j.compedu.2010.02.023

Nguyen, T. (2015). The Effectiveness of Online Learning: Beyond No Significant Difference and Future Horizons. MERLOT Journal of Online Learning and Teaching.

Panigrahi, R., Srivastava, P. R., \& Sharma, D. (2018). Online learning: Adoption, continuance, and learning outcome-A review of literature. In International Journal of Information Management. https://doi.org/10.1016/j.ijinfomgt.2018.05.005

Park, C. W., \& Kim, D. gook. (2020). Exploring the Roles of Social Presence and Gender Difference in Online Learning. Decision Sciences Journal of Innovative Education, 18(2), 291-312. https://doi.org/10.1111/dsji.12207

Rochmahwati, P. (2015). FOSTERING STUDENTS' CRITICAL THINKING BY PROJECT-BASED LEARNING. Journal on English as a Foreign Language. https://doi.org/10.23971/jefl.v5i1.90

Rotgans, J. I., \& Schmidt, H. G. (2011). Cognitive engagement in the problem-based learning classroom. Advances in Health Sciences Education. https://doi.org/10.1007/s10459-011-9272-9

Saunders-Stewart, K. S., Gyles, P. D. T., Shore, B. M., \& Bracewell, R. J. (2015). Student outcomes in inquiry: students' perspectives. Learning Environments Research. https://doi.org/10.1007/s10984-015- 


\section{5-2}

Silalahi, T. F., \& Hutauruk, A. F. (2020). The Application of Cooperative Learning Model during Online Learning in the Pandemic Period. Budapest International Research and Critics Institute (BIRCIJournal): Humanities and Social Sciences, 3(3), 1683-1691.

Sirisrimangkorn, L. (2018). The Use of Project-based Learning Focusing on Drama to Promote Speaking Skills of EFL Learners. Advances in Language and Literary Studies, 9(6), 14. https://doi.org/10.7575/aiac.alls.v.9n.6p.14

Spronken-Smith, R., Walker, R., Batchelor, J., O'Steen, B., \& Angelo, T. (2012). Evaluating student perceptions of learning processes and intended learning outcomes under inquiry approaches. Assessment and Evaluation in Higher Education, 37(1), 57-72. https://doi.org/10.1080/02602938.2010.496531

Sutarsyah, C. (2017). An analysis of student's speaking anxiety and its effect on speaking performance. IJELTAL (Indonesian Journal of English Language Teaching and Applied Linguistics), 1(2), 143-152.

Ul-Haq, Z., Khurram, B. A., \& Bangash, A. K. (2017). Development of speaking skills through activity based learning at the elementary level. Egitim Arastirmalari - Eurasian Journal of Educational Research, 2017(69), 241-252. https://doi.org/10.14689/ejer.2017.69.13 